Supporting Information

\title{
Reconfigurable Transitions between 1- and 2-Dimensional Structures with Bifunctional DNA-Coated Janus Colloids
}

\author{
Joon Suk Oh, ${ }^{1,2}$ Gi-Ra Yi, ${ }^{2, *}$ and David J. Pine ${ }^{1,3, *}$
}

${ }^{1}$ Center for Soft Matter Research and Department of Physics, New York University, New York, NY 10003, USA

2 Department of Chemical Engineering, Sungkyunkwan University, Suwon, 16419, Republic of Korea

${ }^{3}$ Department of Chemical and Biomolecular Engineering, New York University, Brooklyn, NY, 11201, USA 


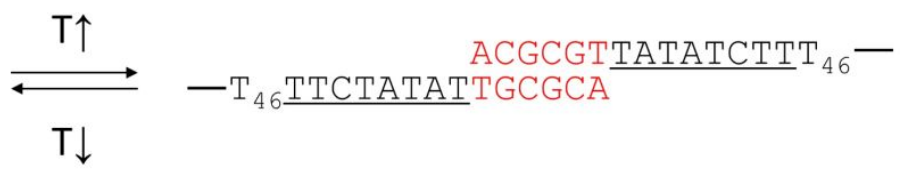

$$
\mathrm{P}_{\mathrm{H}^{-}} \text {-D duplex }
$$

$$
\mathrm{P}_{\mathrm{H}^{-}} \mathrm{P}_{\mathrm{H}} \text { duplex }
$$

Figure S1. Temperature-responsive formation of $\mathrm{P}_{\mathrm{H}}-\mathrm{P}_{\mathrm{H}}$ or $\mathrm{P}_{\mathrm{H}}-\mathrm{D}$ duplex.

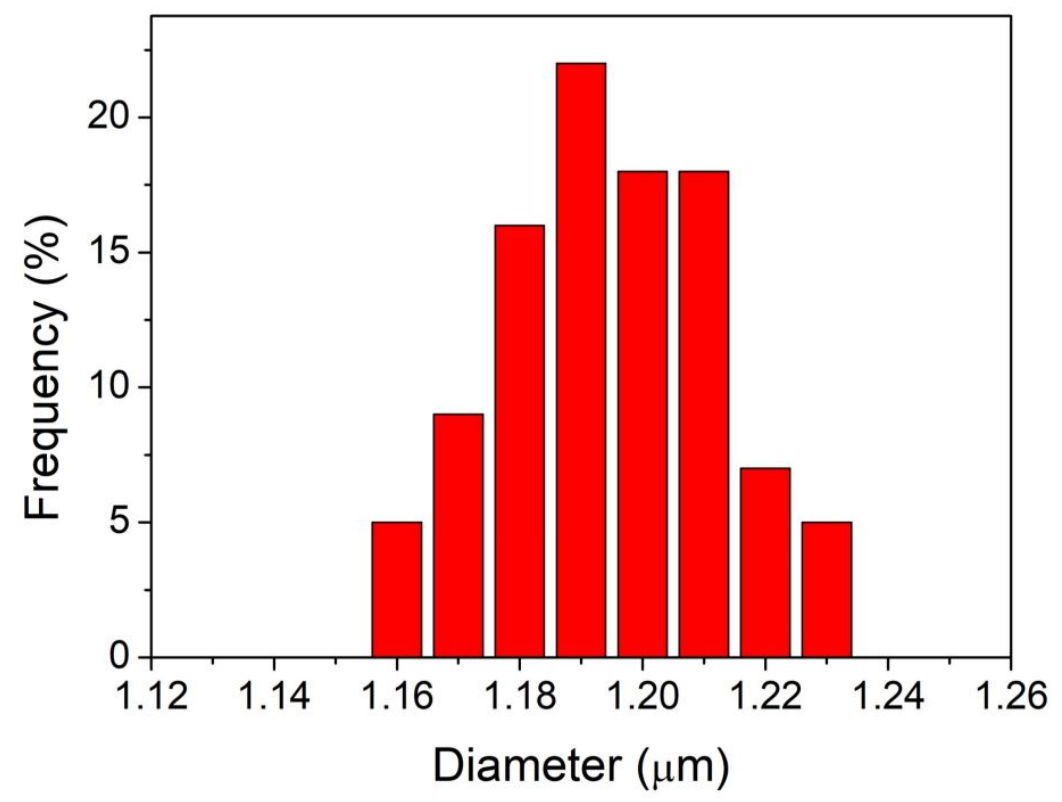

Figure S2. Size distribution of Janus particles.

Table S1. Thermodynamic parameters of DNA duplex (calculated using the DINAMelt Web Server, strand concentration: $1 \mathrm{mM}, \mathrm{NaCl}$ concentration: $0.5 \mathrm{M}$, at $37{ }^{\circ} \mathrm{C}$ ).

\begin{tabular}{|l|l|l|l|l|}
\hline DNA duplex & $\Delta G(\mathrm{kcal} / \mathrm{mol})$ & $\Delta H(\mathrm{kcal} / \mathrm{mol})$ & $\Delta S(\mathrm{cal} / \mathrm{mol} \cdot \mathrm{K})$ & $\begin{array}{l}\text { Melting } \\
\text { temperature }\end{array}$ \\
\hline $\mathrm{P}_{\mathrm{H}}-\mathrm{P}_{\mathrm{H}}$ & -6.8 & -43.0 & -116.8 & $56.4^{\circ} \mathrm{C}$ \\
\hline $\mathrm{P}_{\mathrm{L}}-\mathrm{P}_{\mathrm{L}}$ & -4.0 & -36.2 & -103.8 & $34.8^{\circ} \mathrm{C}$ \\
\hline $\mathrm{P}_{\mathrm{H}}-\mathrm{D}$ & -8.4 & -76.7 & -220.1 & $51.1^{\circ} \mathrm{C}$ \\
\hline
\end{tabular}

Video 1. Reconfigurable self-assembly of DNA-coated Janus particles.

Video 2. Colloidal chains of DNA-coated Janus particles. 